\title{
Depression and Psychological-Behavioral Responses Among the General Public in China During the Early Stages of the COVID-19 Pandemic: Survey Study
}

Weiyu Zhang ${ }^{1}$, BM; Xiaoting Yang ${ }^{2}$, AD; Jinfeng Zhao ${ }^{3}$, PhD; Fengzhi Yang ${ }^{1}$, BM; Yajing Jia ${ }^{1}$, BA; Can Cui ${ }^{1}$, BA; Xiaoshi Yang ${ }^{1}, \mathrm{PhD}$

\footnotetext{
${ }^{1}$ Department of Social Medicine, School of Public Health, China Medical University, Shenyang, China

${ }^{2}$ Department of Gastroenterology, Benxi General Hospital, Liaoning Health Industry Group, Benxi, China

${ }^{3}$ The University of Auckland, Auckland, New Zealand
}

\section{Corresponding Author:}

Xiaoshi Yang, $\mathrm{PhD}$

Department of Social Medicine, School of Public Health

China Medical University

No 77 Puhe Road

Shenyang North New Area

Shenyang, 110122

China

Phone: 8618900910796

Email: xsyang@cmu.edu.cn

\section{Abstract}

Background: The COVID-19 pandemic has recently spread dramatically worldwide, raising considerable concerns and resulting in detrimental effects on the psychological health of people who are vulnerable to the disease. Therefore, assessment of depression in members of the general public and their psychological and behavioral responses is essential for the maintenance of health.

Objective: This study aimed to assess the prevalence of depression and the associated factors among the general public during the early stages of the COVID-19 pandemic in China.

Methods: A cross-sectional survey with convenience sampling was conducted from February 11 to 16, 2020, in the early stages of the COVID-19 outbreak in China. A self-administrated smartphone questionnaire based on the Patient Health Questionnaire-9 (PHQ-9) and psychological and behavioral responses was distributed to the general public. Hierarchical multiple regression analysis and multivariate logistic regression analysis were conducted to explore the associated factors of depression.aA cross-sectional survey with convenience sampling was conducted from February 11 to 16, 2020, in the early stages of the COVID-19 outbreak in China. A self-administrated smartphone questionnaire based on the Patient Health Questionnaire-9 (PHQ-9) and psychological and behavioral responses was distributed to the general public. Hierarchical multiple regression analysis and multivariate logistic regression analysis were conducted to explore the associated factors of depression.

Results: The prevalence of depression (PHQ-9 score $\geq 10$ ) among the general public during the COVID-19 pandemic was 182/1342 (13.6\%). Regression analysis indicated that feeling stressed, feeling helpless, persistently being worried even with support, never feeling clean after disinfecting, scrubbing hands and items repeatedly, hoarding food, medicine, or daily supplies, and being distracted from work or study were positively associated with depression, while social support and being calm were negatively associated with depression.

Conclusions: The general public suffered from high levels of depression during the early stages of the COVID-19 pandemic. Thus, COVID-19-related mood management and social support should be provided to attenuate depression in the general public.

(J Med Internet Res 2020;22(9):e22227) doi: 10.2196/22227

\section{KEYWORDS}

depression; COVID-19; social support; the general public 


\section{Introduction}

COVID-19 is a highly infectious disease that was identified at the end of 2019 and has been listed as Public Health Emergency of International Concern by the World Health Organization $[1,2]$. COVID-19 rapidly spread to 31 provinces, municipalities, and autonomous regions in China and then spread worldwide, developing into a serious global pandemic and resulting in harm to public health, the global economy, and social development. As of 4 PM CST, July 2, 2020, 10,726,907 confirmed cases and 514,458 deaths have been reported from 26 countries around the world; 85,264 confirmed cases and 4648 deaths have been reported in China [3,4].

The unexpected outbreak of COVID-19 resulted in adverse impacts on the general public, restricting normal activities and disrupting festive plans. A series of immediate emergency responses were initiated by Chinese government to prevent the spread of COVID-19. The responses included sealing off cities and provinces, restrictions on travel, control of civilian air traffic, self-quarantine, delaying the resumption of work and school, and setting up targeted hospitals to receive and treat patients. The rapid spread of COVID-19 and uncertainty related to the disease have created a great deal of stress and difficult predicaments for the public; this has resulted in the emergence of mental disorders, such as depression and anxiety [5]. Scarcities of medicine and personal protective equipment (eg, antibiotics, masks, alcohol sanitizer) and basic food supplies (eg, cereals and vegetables) during the earliest weeks of the pandemic seriously affected the mental health of the public $[6,7]$. Recent studies revealed that extensive exposure to COVID-19 pandemic stress can render the public vulnerable to depression [8].

The psychological and behavioral responses to the COVID-19 pandemic can be vulnerability factors of mental disorders during pandemics $[9,10]$. Previous research has indicated that adverse psychological and behavioral responses to public health emergencies may exacerbate the spread of disease and induce the development of mental disorders such as acute stress disorder, panic attacks, posttraumatic stress disorder, anxiety and depression, and even suicidal tendencies [11-17]. However, the patterns of psychological responses to pandemics are various and unpredictable [18], and they can have considerable influences on the psychological health of the public. A great number of previous studies indicate that negative emotionality, maladaptive cognitive style, and low levels of optimism are associated with the risks of negative psychological impacts $[9,19,20]$. People who overestimate threats or lack tolerance of uncertainty in pandemics can become highly worried and anxious during pandemics [21]. Perception of stress and helplessness arising from the stressful situations of the epidemic could have direct effects on the mental health of individuals and lead to prevalence of depression and anxiety [22,23]. Moreover, psychoneuroimmunology studies indicate that people with predisposition to emotional disorders may be particularly vulnerable as a result of immune responses [24,25]. However, positive emotions such as optimism play a moderating role in the relationship between stress and depression, and lower optimism is associated with affective disorders [26,27].
Additionally, it has been observed that during pandemics, people can share negative emotions, including disappointment, anger, stress, fear, and anxiety, in social life; this is also known as emotional contagion [28].

According to the cognitive-behavioral model of health anxiety, people who experience excessively high health anxiety are likely to become highly anxious during a pandemic and engage in maladaptive behaviors, such as excessive hand washing $[9,18]$. Studies of the concept of the behavioral immune system indicate that people can respond to pandemics excessively (ie, to medically unnecessary levels) and may avoid infection-related contaminants [9,29]. The information-motivation-behavior skill model and the modified behavioral framework mentioned in recent studies indicate that motivation, behavior skills and positive perception of risk have direct effects on health behaviors [30,31]. Conversely, to maintain health and avoid infection, the general public may also behave irrationally (eg, superstitious behaviors, overdose of vitamins, and use of herbal supplements or even folk remedies) when people are excessively worried or anxious during pandemics $[32,33]$. In a recent study, according to the conceptual model of Stimulus-Organism-Response, governance such as lockdown measures taken to cut off channels of infection decreased psychological distance, leading to a buffer effect on perceived risks and anxiety [34]. Adversity in pandemics, such as economic depression and shortage of supplements, can lead to antisocial behaviors such as violence, rioting, looting, and even civil unrest and mass panic [35]. Scientific prediction and appropriate guidance of public behaviors have important implications for people's mental health [36,37].

Social support, which is perceived as care or help from others, has a protective effect on depression by regulating stress, as presented in previous studies [38,39], and it is closely associated with the generation, control, and prevention of mental disorders. Adequate social support and appropriate sources of support are beneficial to the public health because they can release stress, maintain individuals' emotional responses, and prevent mental symptoms [40].

The COVID-19 pandemic has resulted in adverse effects on public mental health, which has recently raised considerable concerns $[41,42]$. Studies have been conducted to assess and prevent psychological health crises during the outbreak of COVID-19 [43]. As a result of the pandemic, the public has reported discomforts such as heavy mental health burdens, poor sleep quality, and psychological distress [44-48]. Therefore, in our study, we aimed to appraise depression and explore its associated factors, including psychological responses, behavioral responses, and social support, among the general public during the early stages of the COVID-19 pandemic. Our findings can be used to provide evidence-based advice on early psychological and behavioral interventions to reduce depression in the general public. 


\section{Methods}

\section{Participants, Procedure, and Ethics Statement}

A cross-sectional survey with convenience sampling was conducted in mainland China from February 11 to 16, 2020. A web link and quick response code were distributed via WeChat, a widely used social network platform in China, to collect self-administrated questionnaires with support from the Environmental Health Institute at China Medical University. Participants anonymously completed a questionnaire in 15 to 20 minutes comprising questions based on the Patient Health Questionnaire-9 (PHQ-9) and concerning psychological and behavioral responses to the COVID-19 pandemic. Participants included in this study met the following inclusion criteria: aged $\geq 18$ years; able to read and write Chinese; able to use WeChat to complete the questionnaire independently; willing to participate and provide signed web-based informed consent. Any participant meeting one or more of the following criteria was excluded: receiving treatment for any psychological illness; having significant visual impairment; having a history of drug dependence; having been diagnosed with a disease that would prevent them from completing the questionnaire independently.

This survey recruited a total of 1675 adults from the general public in 3 municipalities and 22 provinces or autonomous regions in China. Each participant was well informed of the aims, funding, and contents of the questionnaire and the commitment to the privacy of the participants. Questionnaires that were answered completely and logically were regarded as valid. A total of 1342/1675 participants provided valid answers to the questionnaire, resulting in a valid response rate of $80.12 \%$. This study conformed to ethical standards and was conducted in accordance with the Helsinki Declaration as revised in 1989. The Ethics Committee of China Medical University approved the protocols of this study.

\section{Demographic Characteristics of the Participants}

The demographic characteristics of the participants that were collected included gender (male, female), age ( $\leq 35$ years, $>35$ years), marital status (married, other), occupation, education, and monthly income. Age was categorized according to proportionality, population distribution, and previous studies on the relationship between age and use of WeChat $[49,50]$. Occupation was categorized as government worker/civil servant/village committee worker/enterprise employee, health care worker, student, teacher/lawyer/journalist, and other. Education was categorized as below junior college, junior college, and bachelor's degree and above. Monthly income (RMB) was classified as $\leq ¥ 5000$ ( $\leq$ US $\$ 725.19$ ), $¥ 5001$ to $¥ 10,000$ (US $\$ 725.34$ to $\$ 1,450.39$ ), and $>¥ 10,000$ (>US $\$ 1,450.39)$.

\section{Measurement of Depression}

Depression was assessed using the 9-item PHQ-9, which is one of the most widely used tools to assess depression [51]. Each item asked about the situation in the past two weeks using a 4-point Likert-type scale with choices of "not at all," "a few days," "more than half of the two weeks," and "nearly every day," giving a total score between 0 and 21. A score above 10 is regarded to be indicative of depression [52-55]. The Cronbach $\alpha$ coefficient of the PHQ-9 in this study was .91.

\section{Measurement of Psychological Responses}

Psychological responses were measured by self-developed questions. Psychological responses included "feeling stressed," "feeling helpless," "persistently being worried even with support," "being calm," and "being optimistic." Answers were grouped into three categories of "disagree," "not sure," and "agree" to assess the participants' psychological responses during the past two weeks.

\section{Measurement of Behavioral Responses}

Behavioral responses were measured by self-developed questions. Options for reflecting behavioral responses for this study included "never feeling clean after disinfecting; scrubbing hands and items repeatedly" (answers were "no," "sometimes," and "always"), "hoarding food, medicine, or daily supplies," "social avoidance to avoid infection," and "being distracted from work or study." Answers were grouped into 3 categories of "disagree," "not sure," and "agree" to evaluate the participants' behavioral responses during the past two weeks.

\section{Measurement of Social Support}

Social support was assessed by a "yes or no" question that asked whether people had received social support in the past two weeks.

\section{Statistical Analyses}

All analyses were performed using SPSS version 23.0 for Windows (IBM Corporation). A two-tailed probability value $<.05$ was considered statistically significant. We used $t$ tests and one-way analysis of variance to compare differences in depression among categorical variables. Hierarchical multiple regression (HMR) analysis was conducted to test incremental variance using the following independent variables: Step 1: demographic characteristics of the general public; Step 2: psychological responses to the COVID-19 pandemic; Step 3: behavioral responses to the COVID-19 pandemic; and Step 4: social support. The depression scores were continuous in HMR and used as the dependent variables. Standardized parameter estimates (standardized $\beta$ ) were used to compare the magnitude of associations of the independent variables. The depression scores in the multivariate logistic regression analysis were binary (depression or no depression) with a cutoff score of 10 . Multivariate logistic regression analysis was performed to explore risk factors associated with depression using odds ratios (ORs). Among all categorically independent variables, items for which more than $95 \%$ of individuals had the same response were not included in the data analysis. A two-tailed $P$ value $<.05$ was considered to be statistically significant.

\section{Results}

\section{Demographic Characteristics and Depression Distribution of the Participants}

A total of 1342 subjects participated in this study, giving a valid response rate of $1342 / 1675(80.12 \%)$. The distribution of the demographic characteristics of the participants, prevalence of 
depression, and univariate analysis of depression are listed in Table 1 . The prevalence of depression among the general public was $182 / 1342(13.60 \%)$.

The 1342 participants included 500 men (37.26\%) and 842 women (62.74\%). Approximately one-third of the participants $(467 / 1342,35.77 \%)$ had a bachelor's degree or higher degree. Depression scores for the participants who were aged $<35$ years were significantly higher than those of the other participants $(P=.001)$. Participants who were married tended to have lower depression scores than participants who were not $(P<.001)$. Government workers, civil servants, village committee workers, enterprise employees, and health care workers had lower depression scores than those engaging in other occupations $(P<.001)$. 
Table 1. Characteristics of the general public and distribution of depression in China during the early stages of the COVID-19 pandemic (N=1342).

\begin{tabular}{|c|c|c|c|c|c|}
\hline Variable & Total, $\mathrm{n}(\%)$ & $\begin{array}{l}\text { Depression, } \mathrm{n} \\
(\%)\end{array}$ & $\begin{array}{l}\text { No depression, } \\
\mathrm{n}(\%)\end{array}$ & $\begin{array}{l}\text { Depression score, } \\
\text { mean (SD) }\end{array}$ & $P$ value \\
\hline \multicolumn{6}{|l|}{ Demographic characteristics } \\
\hline Gender & & & & & .30 \\
\hline Male & $500(37.26)$ & $66(13.20)$ & $434(86.80)$ & $4.04(5.68)$ & \\
\hline Female & $842(62.74)$ & $116(13.78)$ & $726(86.22)$ & $4.35(5.13)$ & \\
\hline Age (years) & & & & & .001 \\
\hline$\leq 35$ & $597(44.49)$ & $98(16.42)$ & $499(83.58)$ & $4.80(5.57)^{\mathrm{a}}$ & \\
\hline$>35$ & $745(55.51)$ & $84(11.28)$ & $661(88.72)$ & $3.78(5.11)$ & \\
\hline Marital status & & & & & $<.001$ \\
\hline Married & $898(66.92)$ & $107(11.92)$ & $791(88.08)$ & $3.85(5.07)$ & \\
\hline Other & $444(33.09)$ & $75(16.89)$ & $369(83.11)$ & $5.03(5.77)^{\mathrm{a}}$ & \\
\hline Occupation & & & & & $<.001$ \\
\hline $\begin{array}{l}\text { Government worker, civil servant, } \\
\text { village committee worker, or enter- } \\
\text { prise employee }\end{array}$ & $377(28.09)$ & $34(9.02)$ & $343(90.98)$ & $3.56(4.99)$ & \\
\hline Health care worker & $279(20.79)$ & $30(10.75)$ & $249(89.25)$ & $3.59(4.71)$ & \\
\hline Student & $203(15.13)$ & $37(18.23)$ & $166(81.77)$ & $5.00(5.29)^{\mathrm{a}}$ & \\
\hline Teacher, lawyer, or journalist & $244(18.18)$ & $37(15.16)$ & $207(84.84)$ & $4.48(5.36)^{\mathrm{b}}$ & \\
\hline Other & $239(17.81)$ & $44(18.41)$ & $195(81.59)$ & $5.19(6.30)^{\mathrm{a}}$ & \\
\hline Education & & & & & .08 \\
\hline Below junior college & $166(12.37)$ & $165(15.15)$ & $141(84.85)$ & $4.41(5.74)$ & \\
\hline Junior college & 709 (52.83) & $107(15.09)$ & $602(84.91)$ & $4.49(5.67)^{\mathrm{b}}$ & \\
\hline Bachelor's degree and above & $467(34.80)$ & $50(10.71)$ & 417 (89.29) & $3.80(4.62)$ & \\
\hline Monthly income (¥) & & & & & .006 \\
\hline$\leq 5000$ & $445(33.16)$ & $77(17.30)$ & $368(82.70)$ & $3.72(4.98)$ & \\
\hline $5001-10,000$ & $535(39.87)$ & $53(9.91)$ & $482(90.09)$ & $3.21(4.17)$ & \\
\hline$>10,000$ & $362(26.97)$ & $52(14.36)$ & $310(85.64)$ & $3.54(4.44)$ & \\
\hline \multicolumn{6}{|l|}{ Psychological Responses } \\
\hline Feeling stressed & & & & & $<.001$ \\
\hline Disagree & $370(27.57)$ & $16(4.32)$ & $354(95.68)$ & $1.72(3.48)$ & \\
\hline Not sure & $634(47.24)$ & $63(9.94)$ & $571(90.06)$ & $3.85(4.48)^{\mathrm{a}}$ & \\
\hline Agree & $338(25.19)$ & $103(30.47)$ & $235(69.53)$ & $7.74(6.60)^{\mathrm{a}}$ & \\
\hline Feeling helpless & & & & & $<.001$ \\
\hline Disagree & $554(41.28)$ & $103(18.59)$ & $451(81.41)$ & $2.44(4.18)$ & \\
\hline Not sure & $443(33.01)$ & $49(11.06)$ & $394(88.94)$ & $4.09(4.61)^{\mathrm{a}}$ & \\
\hline Agree & $345(25.71)$ & $30(8.70)$ & $315(91.30)$ & $7.32(6.41)^{\mathrm{a}}$ & \\
\hline \multicolumn{3}{|c|}{ Persistently being worried even with support } & & & $<.001$ \\
\hline Disagree & $648(48.29)$ & $24(3.70)$ & $624(96.30)$ & $2.05(3.46)$ & \\
\hline Not sure & $313(23.32)$ & $37(11.82)$ & $276(88.18)$ & $4.30(4.67)^{\mathrm{a}}$ & \\
\hline Agree & $381(28.39)$ & $121(31.76)$ & $260(68.24)$ & $7.91(6.39)^{\mathrm{a}}$ & \\
\hline
\end{tabular}




\begin{tabular}{|c|c|c|c|c|c|}
\hline Variable & Total, n (\%) & $\begin{array}{l}\text { Depression, } \mathrm{n} \\
(\%)\end{array}$ & $\begin{array}{l}\text { No depression, } \\
\mathrm{n}(\%)\end{array}$ & $\begin{array}{l}\text { Depression score, } \\
\text { mean (SD) }\end{array}$ & $P$ value \\
\hline \multicolumn{5}{|l|}{ Being calm } & \multirow[t]{4}{*}{$<.001$} \\
\hline Agree & $521(38.82)$ & $33(6.33)$ & $488(93.67)$ & $2.74(4.44)$ & \\
\hline Not sure & $548(40.83)$ & $73(13.32)$ & $475(86.68)$ & $4.36(4.94)^{\mathrm{a}}$ & \\
\hline Disagree & $273(20.35)$ & $76(27.84)$ & $197(72.16)$ & $6.86(6.53)^{\mathrm{a}}$ & \\
\hline \multicolumn{5}{|l|}{ Being optimistic } & \multirow[t]{4}{*}{$<.001$} \\
\hline Agree & $410(30.55)$ & $39(9.51)$ & $371(90.49)$ & $3.32(5.10)$ & \\
\hline Not sure & $425(31.67)$ & $42(9.88)$ & $383(90.12)$ & $3.63(4.50)$ & \\
\hline Disagree & $507(37.78)$ & $101(19.92)$ & $406(80.08)$ & $5.50(5.99)^{\mathrm{a}}$ & \\
\hline \multicolumn{6}{|l|}{ Behavioral responses } \\
\hline \multicolumn{5}{|c|}{ Never feeling clean after disinfecting; scrubbing hands and items repeatedly } & \multirow[t]{4}{*}{$<.001$} \\
\hline No & $543(40.46)$ & $35(6.45)$ & $508(93.55)$ & $2.73(4.41)$ & \\
\hline Sometimes & $402(29.96)$ & $60(14.93)$ & $342(85.07)$ & $4.83(4.96)^{\mathrm{a}}$ & \\
\hline Always & $397(29.58)$ & $87(21.91)$ & $310(78.09)$ & $5.71(6.28)^{\mathrm{a}}$ & \\
\hline \multicolumn{4}{|c|}{ Hoarding food, medicine, or daily supplies } & & \multirow[t]{4}{*}{$<.001$} \\
\hline Disagree & $595(44.34)$ & $55(9.24)$ & $540(90.76)$ & $3.07(4.60)$ & \\
\hline Not sure & $492(36.66)$ & $57(11.59)$ & $435(88.41)$ & $4.27(4.66)^{\mathrm{a}}$ & \\
\hline Agree & $255(19.00)$ & $70(27.45)$ & $185(72.55)$ & $6.89(7.00)^{\mathrm{a}}$ & \\
\hline \multicolumn{4}{|c|}{ Social avoidance to avoid infection } & & \multirow[t]{4}{*}{.053} \\
\hline Disagree & $275(20.49)$ & $36(13.09)$ & $239(86.91)$ & $3.89(5.24)$ & \\
\hline Not sure & $547(40.76)$ & $63(11.52)$ & $484(88.48)$ & $3.99(4.76)$ & \\
\hline Agree & $520(38.75)$ & $83(15.96)$ & $437(84.04)$ & $4.68(5.93)$ & \\
\hline \multicolumn{2}{|c|}{ Being distracted from work or study } & & & & \multirow[t]{4}{*}{$<.001$} \\
\hline Disagree & $443(33.01)$ & $3(0.68)$ & $440(99.32)$ & $1.23(2.33)$ & \\
\hline Not sure & $379(28.24)$ & $32(8.44)$ & $347(91.56)$ & $3.27(3.90)^{\mathrm{a}}$ & \\
\hline Agree & $520(38.75)$ & $147(28.27)$ & $373(71.73)$ & $7.51(6.24)^{\mathrm{a}}$ & \\
\hline \multicolumn{2}{|l|}{ Social support } & & & & \multirow[t]{3}{*}{$<.001$} \\
\hline Yes & $1198(89.27)$ & $146(12.19)$ & $1052(87.81)$ & $4.00(5.08)$ & \\
\hline No & $144(10.73)$ & $36(25.00)$ & $108(75.00)$ & $6.21(6.89)^{\mathrm{a}}$ & \\
\hline
\end{tabular}

${ }^{\text {a }}$ Significant at the 0.01 level (two-tailed).

${ }^{\mathrm{b}}$ Significant at the 0.05 level (two-tailed).

${ }^{\mathrm{c}} 1 ¥=$ US $\$ 0.15$.

\section{Psychological and Behavioral Responses to the COVID-19 Pandemic}

The distribution of depression scores according to psychological and behavioral responses to the COVID-19 pandemic are shown in Table 1. The participants who disagreed that they felt stressed or helpless tended to have lower depression scores than those who agreed or were not sure $(P<.001)$. Depression scores were lower among participants who were persistently worried even with support $(P<.001)$. The depression scores for the individuals who agreed that they were calm or optimistic about the COVID-19 pandemic were significantly lower $(P<.001)$.
The participants who never felt clean after disinfecting and who scrubbed their hands and items repeatedly had significantly higher depression scores $(P<.001)$. Participants who agreed that they hoarded food, medicine, or daily supplies tended to have significantly higher depression scores $(P<.001)$. Scores were higher for the participants who agreed that they were distracted from work or study $(P<.001)$.

The results also showed that participants who reported that they did not receive any support from others when they had difficulties during the COVID-19 pandemic had a significantly higher score of depression than those who received social support $(P<.001)$. 


\section{Risk Factors of Depression}

Table 2 shows the final results of the HMR models of depression among the general public. A total of $42.1 \%$ of the variance was explained by the final model. The $R^{2}$ changes indicated that the incremental variances explained by each block of variables were $3.1 \%, 28.6 \%, 10.1 \%$, and $0.3 \%$ for demographic characteristics, psychological responses, behavioral responses, and social support, respectively. In the final model of the HMR and the forest plot (Figure 1), the risk factors of depression included feeling stressed; feeling helpless; persistently being worried, even with support; never feeling clean after disinfecting, and scrubbing hands and items repeatedly; hoarding food, medicine, or daily supplies; and being distracted from work or study (all $P<.01)$. However, being calm and social support were negatively associated with depression. 
Table 2. Hierarchical linear regression analysis of depression among the general population in China during the early stages of the COVID-19 pandemic.

\begin{tabular}{|c|c|c|c|c|c|c|}
\hline Variable & $\beta$ & Standardized $\beta$ & $95 \% \mathrm{CI}$ & $P$ value & Adjusted $R^{2}$ & $\Delta R^{2}$ \\
\hline Demographic characteristics & & & & & 0.023 & 0.031 \\
\hline Gender (male vs female) & -0.429 & -0.039 & -0.926 to 0.068 & .09 & & \\
\hline Age ( $>35$ years vs $\leq 35$ years) & -0.082 & -0.008 & -0.675 to 0.511 & .79 & & \\
\hline Marital status (married vs other) & -0.669 & -0.059 & & .06 & & \\
\hline \multicolumn{7}{|l|}{ Occupation } \\
\hline Health care worker & 0.407 & 0.031 & -0.259 to 1.073 & .23 & & \\
\hline Student & 0.277 & 0.019 & -0.599 to 1.154 & .54 & & \\
\hline Teacher, lawyer, or journalist & 0.745 & 0.054 & 0.066 to 1.425 & $.03^{\mathrm{a}}$ & & \\
\hline Other & 0.502 & 0.036 & -0.188 to 1.192 & .15 & & \\
\hline \multicolumn{7}{|l|}{ Education } \\
\hline $\begin{array}{l}\text { Below junior college vs bachelor's de- } \\
\text { gree and above }\end{array}$ & 0.437 & 0.027 & -0.299 to 1.174 & .25 & & \\
\hline $\begin{array}{l}\text { Junior college vs bachelor's degree and } \\
\text { above }\end{array}$ & 0.433 & 0.040 & -0.053 to 0.919 & .08 & & \\
\hline \multicolumn{7}{|l|}{ Monthly income (¥) } \\
\hline$\leq 5000$ vs $>10,000$ & 0.382 & 0.034 & -0.226 to 0.991 & .22 & & \\
\hline $5001-10,000$ vs $>10,000$ & -0.231 & -0.021 & -0.791 to 0.330 & .42 & & \\
\hline Psychological responses & & & & & 0.306 & 0.286 \\
\hline \multicolumn{7}{|l|}{ Feeling stressed } \\
\hline Not sure vs disagree & -0.161 & -0.015 & -0.805 to 0.482 & .62 & & \\
\hline Agree vs disagree & 1.631 & 0.133 & 0.813 to 2.448 & $<.001^{\mathrm{c}}$ & & \\
\hline \multicolumn{7}{|l|}{ Feeling helpless } \\
\hline Not sure vs disagree & 0.665 & 0.059 & 0.097 to 1.234 & $.02^{\mathrm{a}}$ & & \\
\hline Agree vs disagree & 1.717 & 0.141 & 1.076 to 2.358 & $<.001^{\mathrm{c}}$ & & \\
\hline \multicolumn{7}{|l|}{ Persistently being worried even with support } \\
\hline Not sure vs disagree & 0.822 & 0.065 & 0.156 to 1.488 & $.016^{\mathrm{a}}$ & & \\
\hline Agree vs disagree & 2.016 & 0.170 & 1.299 to 2.733 & $<.001^{\mathrm{c}}$ & & \\
\hline \multicolumn{7}{|l|}{ Being calm } \\
\hline Agree vs disagree & -1.365 & -0.125 & -2.081 to -0.649 & $<.001^{\mathrm{c}}$ & & \\
\hline Not sure vs disagree & -0.477 & -0.044 & -1.115 to 0.160 & .14 & & \\
\hline \multicolumn{7}{|l|}{ Being optimistic } \\
\hline Agree vs disagree & 0.318 & 0.027 & -0.296 to 0.933 & .31 & & \\
\hline Not sure vs disagree & -0.407 & -0.035 & -0.968 to 0.153 & .15 & & \\
\hline Behavioral responses & & & & & 0.404 & 0.101 \\
\hline \multicolumn{7}{|c|}{ Never feeling clean after disinfecting; scrubbing hands and items repeatedly } \\
\hline Sometimes vs no & 0.175 & 0.015 & -0.398 to 0.748 & .55 & & \\
\hline Always vs no & 0.803 & 0.069 & 0.231 to 1.374 & $.006^{\mathrm{c}}$ & & \\
\hline \multicolumn{7}{|l|}{ Hoarding food, medicine, or daily supplies } \\
\hline Not sure vs disagree & -0.157 & -0.014 & -0.683 to 0.369 & .56 & & \\
\hline Agree vs disagree & 1.393 & 0.102 & 0.686 to 2.099 & $<.001^{\mathrm{c}}$ & & \\
\hline
\end{tabular}




\begin{tabular}{clllll}
\hline Variable & $\beta$ & Standardized $\beta$ & $95 \%$ CI & $P$ value & Adjusted $R^{2} \Delta R^{2}$ \\
\hline Not sure vs disagree & -0.421 & -0.039 & -1.060 to 0.218 & .20 & .72 \\
$\quad$ Agreed vs disagree & -0.121 & -0.011 & -0.793 to 0.550 & & \\
$\quad \begin{array}{l}\text { Being distracted from work or study } \\
\quad \text { Not sure vs disagree }\end{array}$ & 0.951 & 0.080 & 0.311 to 1.590 & $.004^{\mathrm{c}}$ & \\
$\quad$ Agree vs disagree & 3.842 & 0.351 & 3.219 to 4.464 & $<.001^{\mathrm{c}}$ & 0.406 \\
Social support (yes vs no) & -0.943 & -0.055 & -1.682 to -0.205 & $.012^{\mathrm{a}}$ & 0.003 \\
\hline
\end{tabular}

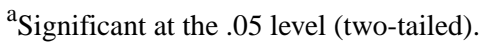

$\mathrm{b}_{1} ¥=$ US $\$ 0.15$.

${ }^{\mathrm{c}}$ Significant at the .01 level (two-tailed).

Figure 1. Forest plot of the risk factors of depression (hierarchical multiple regression).

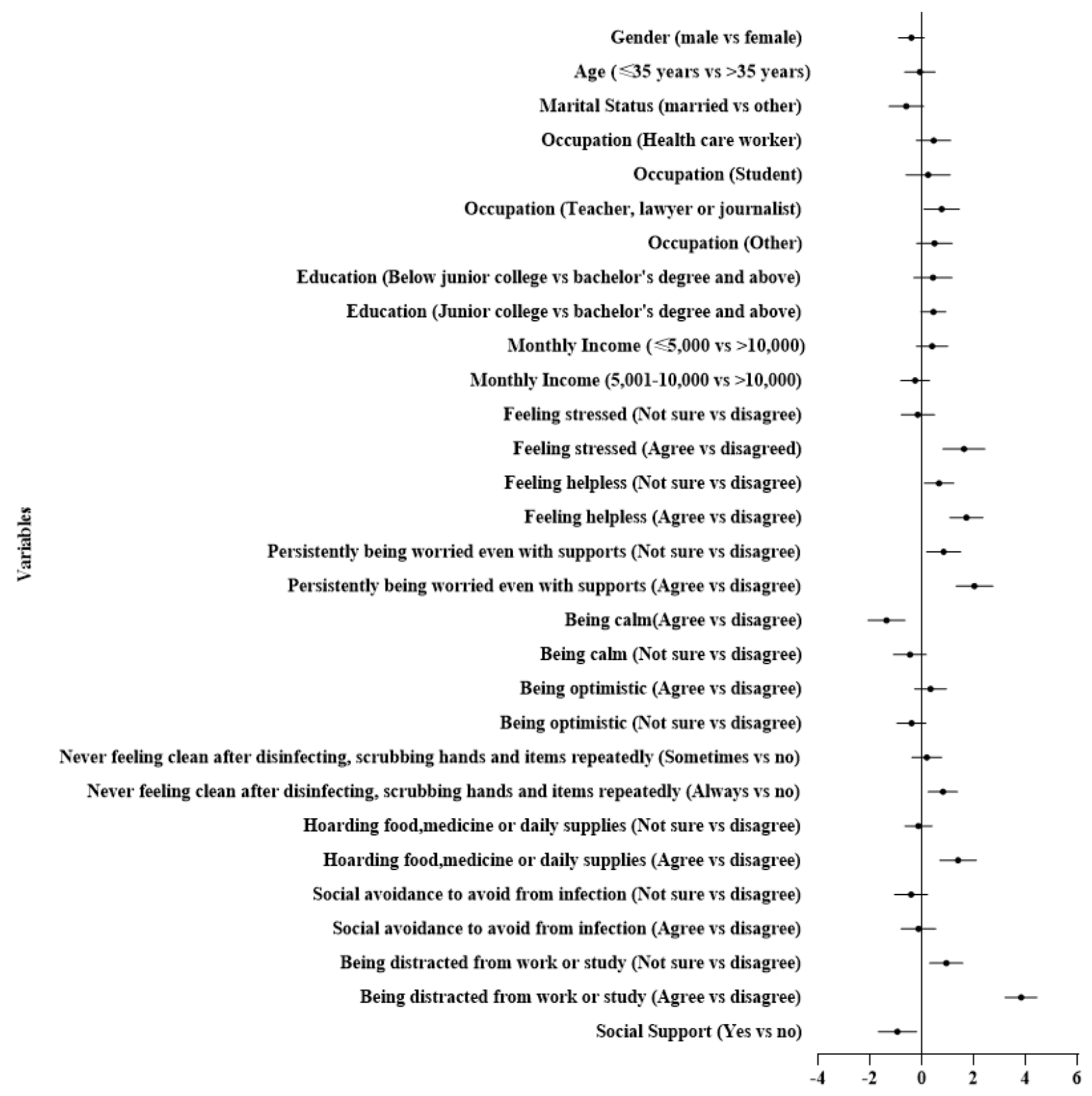

Table 3 presents the results of the multivariate logistic regression persistently being worried even with support (OR 3.315, 95\% analysis. Feeling helpless (OR 2.341, 95\% CI 1.367-4.009), CI 1.696-6.479), never feeling clean after disinfecting and 
scrubbing hands and items repeatedly (OR 1.941, 95\% CI 1.153-3.267), hoarding food, medicine, or daily supplies (OR $1.822,95 \%$ CI 1.012-3.279), and being distracted from work or study (OR 27.225, 95\% CI 8.243-89.918) increased the risk of depression. However, being calm (OR 0.344, 95\% CI 0.186-0.635) and social support (OR 0.529, 95\% CI 0.308-0.908) decreased the chance of suffering from depression. Additionally, compared with other occupations, teachers, lawyers, and journalists (OR 2.053, 95\% CI 1.117-3.776) had higher chances of depression. In the final model of the multivariate logistic regression and the forest plot (Figure 2), the risk factors of depression included occupation of teacher, lawyer, or journalist; junior college education; feeling helpless; persistently being worried, even with support; never feeling clean after disinfecting and scrubbing hands and items repeatedly; hoarding food, medicine, or daily supplies; and being distracted from work or study (all $P<.01$ ). However, being calm and social support were protective factors of depression. 
Table 3. Multivariate logistic regression analysis exploring factors of depression among the general population in China during the early stages of the COVID-19 pandemic.

\begin{tabular}{|c|c|c|}
\hline Variable & Odds ratio & $95 \% \mathrm{CI}$ \\
\hline \multicolumn{3}{|l|}{ Demographic characteristics } \\
\hline Gender (male vs female) & 0.742 & $0.478-1.150$ \\
\hline Age ( $>35$ years vs $\leq 35$ years) & 0.885 & $0.532-1.474$ \\
\hline Marital status (married vs other) & 0.936 & $0.531-1.651$ \\
\hline \multicolumn{3}{|l|}{ Occupation } \\
\hline Health care worker & 1.530 & $0.804-2.914$ \\
\hline Student & 1.810 & $0.872-3.754$ \\
\hline Teacher, lawyer, or journalist & 2.049 & $1.115-3.768$ \\
\hline Other & 1.403 & $0.765-2.573$ \\
\hline \multicolumn{3}{|l|}{ Education } \\
\hline Below junior college vs bachelor's degree and above & 1.596 & $0.839-3.035$ \\
\hline Junior college vs bachelor's degree and above & 1.572 & $1.018-2.428$ \\
\hline \multicolumn{3}{|l|}{ Monthly income (¥) } \\
\hline$\leq 5000$ vs $>10,000$ & 1.160 & $0.697-1.931$ \\
\hline $5001-10,000$ vs $>10,000$ & 0.617 & $0.374-1.018$ \\
\hline \multicolumn{3}{|l|}{ Psychological responses } \\
\hline \multicolumn{3}{|l|}{ Feeling stressed } \\
\hline Not sure vs disagree & 0.465 & $0.216-1.003$ \\
\hline Agree vs disagree & 1.018 & $0.436-2.376$ \\
\hline \multicolumn{3}{|l|}{ Feeling helpless } \\
\hline Not sure vs disagree & 1.455 & $0.826-2.562$ \\
\hline Agree vs disagree & 2.348 & $1.373-4.016$ \\
\hline \multicolumn{3}{|l|}{ Persistently being worried even with support } \\
\hline Not sure vs disagree & 2.120 & $1.081-4.160$ \\
\hline Agree vs disagree & 3.303 & $1.696-6.433$ \\
\hline \multicolumn{3}{|l|}{ Being calm } \\
\hline Agree vs disagree & 0.345 & $0.188-0.636$ \\
\hline Not sure vs disagree & 0.876 & $0.553-1.386$ \\
\hline \multicolumn{3}{|l|}{ Being optimistic } \\
\hline Agree vs disagree & 1.262 & $0.729-2.186$ \\
\hline Not sure vs disagree & 0.713 & $0.443-1.149$ \\
\hline \multicolumn{3}{|l|}{ Behavioral responses } \\
\hline \multicolumn{3}{|c|}{ Never feeling clean after disinfecting; scrubbing hands and items repeatedly } \\
\hline Sometimes vs no & 1.265 & $0.746-2.145$ \\
\hline Always vs no & 1.942 & $1.158-3.257$ \\
\hline \multicolumn{3}{|l|}{ Hoarding food, medicine, or daily supplies } \\
\hline Not sure vs disagree & 0.655 & $0.397-1.082$ \\
\hline Agree vs disagree & 1.862 & $1.039-3.338$ \\
\hline \multicolumn{3}{|l|}{ Social avoidance to avoid infection } \\
\hline Not sure vs disagree & 0.619 & $0.347-1.104$ \\
\hline Agree vs disagree & 0.746 & $0.404-1.379$ \\
\hline
\end{tabular}




\begin{tabular}{lll}
\hline Variable & Odds ratio & $95 \%$ CI \\
\hline Being distracted from work or study & & $2.648-31.495$ \\
Not sure vs disagree & 9.131 & $8.128-88.430$ \\
Agree vs disagree & 26.810 & $0.305-0.901$ \\
Social support (yes vs no) & 0.524 & \\
\hline
\end{tabular}

${ }^{\mathrm{a}} 1 ¥=$ US $\$ 0.15$.

Figure 2. Forest plot of the risk factors of depression (multivariate logistic regression).

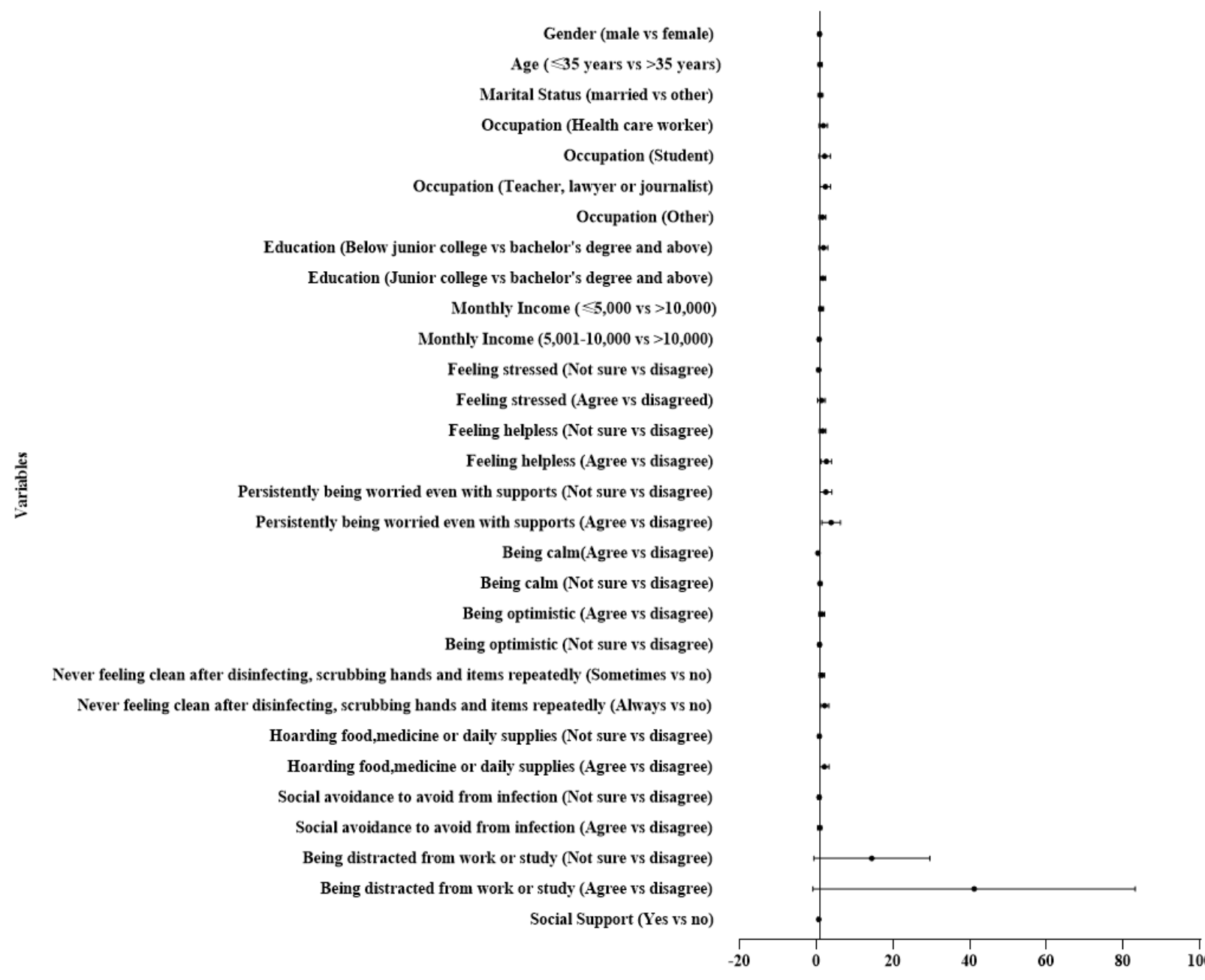

\section{Discussion}

\section{Principal Findings}

This study revealed that $13.6 \%$ of the general public suffered from depression during the early stages of the pandemic of COVID-19 in China. The prevalence of depression was slightly lower than the prevalence before the outbreak of COVID-19 from previous studies [56-58] (13.8\% vs $18.8 \%)$. The results also indicated that the prevalence of depression during the COVID-19 pandemic is almost identical to that during the SARS epidemic (11.9\% vs $18.0 \%)$ among the general public in China $[59,60]$. Most of the research on mental disorders during public health emergencies in China focuses on the psychological status of patients or health care workers; depression in the general public is neglected and untreated [61-64]. The general public are extremely vulnerable to symptoms of depression during the COVID-19 pandemic. People with mental symptoms of depression should be identified and managed in a timely manner to improve their psychological health status [65].

Depression is closely associated with the psychological and behavioral responses of the general public during the COVID-19 pandemic. This study found that psychological responses contributed the most $(28.6 \%)$ to the variance of depression. Feeling stressed, feeling helpless, and feeling persistently worried even with support were positively associated with depression, which is in agreement with previous studies indicating that the increase of perceived susceptibility to the epidemic is associated with the prevalence of mental disorders [66]. Perception of the risks of infection is a possible reason for negative psychological responses to pandemics and is highly 
correlated with distress in individuals [67-69]. Additionally, poor self-rated health status can be causative and can result in psychological burdens and excessive worries about the pandemic [70,71]. In addition, individuals who are worried even when they have support may be more prone to behavior problems, which can exacerbate the symptoms of depression [72,73].

Notably, being calm and optimistic are negatively associated with depression. Calmness and optimism can help people cope with problems rationally and may mediate the negative effects of perception of epidemic-related stress and indirectly attenuate the symptoms of depression [74]. On the other hand, positive cognition of public health emergencies has close correlations with stress and social functions [75]. Additionally, positive psychological capabilities such as calmness and optimism can ameliorate depression, in particular for people who experience higher levels of helplessness [76]. Lessened psychological capabilities can result in high susceptibility to anxiety and depression during negative emotional experiences or periods of adversity such as the COVID-19 pandemic. Thus, psychological management and regulation of the responses to a public health emergency may benefit from consciously controlling stress, helplessness, and worry and from maintaining calm and optimism.

This study showed that depression was significantly linked to behavioral responses. More than half of the participants $(799 / 1342,59.54 \%)$ reported that they never felt clean after they disinfected and scrubbed hands and items repeatedly, and $1067 / 1342(79.51 \%)$ of these members of the general public practiced social avoidance to avoid the infection of COVID-19. Preventive behaviors are key to reducing the spread and impact of a pandemic. However, excessively preventive and avoidant behavioral responses, which possibly resulted from the perceived stress induced by the COVID-19 pandemic, were positively associated with depression. Recent studies have reported that psychological impacts, including depression, anxiety, and stress, are linked with the adoption of precautionary measures to prevent the spread of COVID-19 [16]. For example, using medical preventive equipment and washing after touching contaminated surfaces can provide potential psychological benefits by offering a sense of security and comport for the general public and can prevent the spread of COVID-19. However, these precautionary measures can also have negative effects on individuals' mental health when they become excessive [44,77]. People may feel more susceptible to becoming infected during pandemics. Negative psychological impacts revealed by these behaviors can be easily popularized among the general public. This finding is consistent with other studies showing that protective behaviors such as avoiding sharing of utensils during meals and washing hands frequently increase the likelihood of stress, anxiety, and depression [78]. Health professionals should pay more attention to these behaviors, which can have adverse impacts on mental health, with a view to realizing early warning signs and conducting psychological interventions to protect vulnerable groups [79].

Specifically, social support appeared to be a protective factor for depression. Social support can enhance self-esteem and positive adaptation to stress and combat the detrimental effects of stress or worry on the development of depression [44]. Social support such as positive communications and entertainment may help individuals to recover quickly the from the COVID-19 outbreak [80]. In contrast, lack of social support can result in hostility and uncertainty in social life, thus increasing susceptibility to serious mental disorders, particularly depression [16]. Therefore, adequate and appropriate social support should be provided to prevent the development of mental disorders in the general public.

\section{Limitations}

Several limitations should be acknowledged when presenting our findings. First, this survey was conducted with convenience sampling, which limits our ability to generalize the results of this study to the overall population. Second, this study was based on a self-administrated questionnaire completed via smartphone, which limited the diversity of the sample and the authenticity of the answers. Depression and the associated factors revealed in this study were limited to the early stages of the COVID-19 pandemic.

\section{Conclusion}

The general public in China suffered from high levels of depression during the early stages of the COVID-19 pandemic. Being stressed, feeling helpless or worried, and being distracted from work or study increased the risks of depression. People who experience these adverse psychological responses should be provided with psychological interventions to reduce the symptoms of depression. Moreover, positive emotions and psychological responses such as calmness and optimism decreased the risks of depression and should be encouraged by health professionals and educators. Behavioral responses, including repeated cleaning, hoarding supplies, and distraction from work or study, were not only influencing factors of depression but also expressions of depression. Therefore, early detection and psychological and behavioral interventions should be developed to help people cope rationally with pandemic-related stress and improve the mental health of the general public.

\section{Acknowledgments}

This work was supported by the Research on Behaviors Rules and Emotions and of Public during the Epidemic of COVID-19, Public Behavior Research Project of Prevention and Control of COVID-19, China Medical University (grant number: 121-1210120025). The authors are very grateful to all the study participants and research assistants for data provision and collection. 


\section{Authors' Contributions}

WZ contributed to the acquisition and analysis of data and the drafting and revision of the manuscript. JZ contributed to the revision of the manuscript. Xiaoting Y contributed to the acquisition of data. FY, YJ, and CC contributed to the acquisition and interpretation of data. Xiaoshi $\mathrm{Y}$ was responsible for the conception and design and contributed to the revision of the manuscript.

\section{Conflicts of Interest}

None declared.

\section{References}

1. Guan WJ, Ni ZY, Hu Y, Liang WH, Ou CQ, He JX, China Medical Treatment Expert Group for Covid-19. Clinical Characteristics of Coronavirus Disease 2019 in China. N Engl J Med 2020 Apr 30;382(18):1708-1720 [FREE Full text] [doi: 10.1056/NEJMoa2002032] [Medline: 32109013]

2. 2020 WHO Timeline-COVID-19. World Health Organization. URL: https://www.who.int/news-room/detail/ 27-04-2020-who-timeline---covid-19 [accessed 2020-08-26]

3. 2020 Coronavirus disease (COVID-19) Situation Report-148. World Health Organization. 2020 Jun 16. URL: https://www. who.int/docs/default-source/coronaviruse/situation-reports/20200616-covid-19-sitrep-148-draft.pdf?sfvrsn=9b2015e9 2 [accessed 2020-08-26]

4. Real-time big data of the pandemic of COVID-19. Webpage in Chinese. National Health Commission of the People's Republic of China. URL: https://voice.baidu.com/act/newpneumonia/newpneumonia/?from=osari pc 3\#tab0 [accessed 2020-08-26]

5. Van Bortel T, Basnayake A, Wurie F, Jambai M, Koroma AS, Muana AT, et al. Psychosocial effects of an Ebola outbreak at individual, community and international levels. Bull World Health Organ 2016 Mar 01;94(3):210-214 [FREE Full text] [doi: 10.2471/BLT.15.158543] [Medline: 26966332]

6. Klompas M, Morris CA, Sinclair J, Pearson M, Shenoy ES. Universal Masking in Hospitals in the Covid-19 Era. N Engl J Med 2020 May 21;382(21):e63 [FREE Full text] [doi: 10.1056/NEJMp2006372] [Medline: 32237672]

7. Devi S. Travel restrictions hampering COVID-19 response. Lancet 2020 Apr 25;395(10233):1331-1332 [FREE Full text] [doi: 10.1016/S0140-6736(20)30967-3] [Medline: 32334692]

8. Bao Y, Sun Y, Meng S, Shi J, Lu L. 2019-nCoV epidemic: address mental health care to empower society. Lancet 2020 Feb 22;395(10224):e37-e38 [FREE Full text] [doi: 10.1016/S0140-6736(20)30309-3] [Medline: 32043982]

9. Taylor S. The Psychology of Pandemics: Preparing for the Next Global Outbreak of Infectious Disease. Newcastle upon Tyne, UK: Cambridge Scholars; 2019.

10. Allden K, Jones L, Weissbecker I, Wessells M, Bolton P, Betancourt T, et al. Mental health and psychosocial support in crisis and conflict: report of the Mental Health Working Group. Prehosp Disaster Med 2009;24 Suppl 2:s217-s227 [FREE Full text] [doi: 10.1017/s1049023x00021622] [Medline: 19806544]

11. Shultz JM, Baingana F, Neria Y. The 2014 Ebola outbreak and mental health: current status and recommended response. JAMA 2015 Feb 10;313(6):567-568 [FREE Full text] [doi: 10.1001/jama.2014.17934] [Medline: 25532102]

12. Zhang W, Lee L, Connor KM, Chang C, Lai T, Davidson JR. Symptoms of neurasthenia following earthquake trauma: re-examination of a discarded syndrome. Psychiatry Res 2007 Oct 31;153(2):171-177 [FREE Full text] [doi: 10.1016/j.psychres.2006.04.021] [Medline: 17451809 ]

13. Wu KK, Chan SK, Ma TM. Posttraumatic stress, anxiety, and depression in survivors of severe acute respiratory syndrome (SARS). J Trauma Stress 2005 Feb;18(1):39-42 [FREE Full text] [doi: 10.1002/jts.20004] [Medline: 16281194]

14. Liu T, Chen X, Miao G, Qian M, He Y, Yu X, et al. Recommendations on diagnostic criteria and prevention of SARS-related mental disorders. Article in Chinese. Journal of Clinic Psychology Medicine 2003;13(3):188-191. [doi: 10.3969/j.issn.1005-3220.2003.03.043]

15. Hawkey PM, Bhagani S, Gillespie SH. Severe acute respiratory syndrome (SARS): breath-taking progress. J Med Microbiol 2003 Aug;52(Pt 8):609-613 [FREE Full text] [doi: 10.1099/jmm.0.05321-0] [Medline: 12867552]

16. Ko CH, Yen CF, Yen JY, Yang MJ. Psychosocial impact among the public of the severe acute respiratory syndrome epidemic in Taiwan. Psychiatry Clin Neurosci 2006 Aug;60(4):397-403 [FREE Full text] [doi:

10.1111/j.1440-1819.2006.01522.x] [Medline: 16884438]

17. Vijaya K, Low YY, Chan SP, Foo LL, Lee M, Deurenberg-Yap M. Behaviour of Singaporeans during the SARS outbreak: The impact of anxiety and public satisfaction with media information. Int J Health Promot Educ 2005 Jan;43(1):17-22 [FREE Full text] [doi: 10.1080/14635240.2005.10708030]

18. Goodwin R, Gaines SO, Myers L, Neto F. Initial psychological responses to swine flu. Int J Behav Med 2011 Jun 2;18(2):88-92 [FREE Full text] [doi: 10.1007/s12529-010-9083-z] [Medline: 20195809]

19. Timpano KR, Buckner JD, Richey JA, Murphy DL, Schmidt NB. Exploration of anxiety sensitivity and distress tolerance as vulnerability factors for hoarding behaviors. Depress Anxiety 2009 Apr;26(4):343-353 [FREE Full text] [doi: 10.1002/da.20469] [Medline: 19123454] 
20. Ferguson E. Hypochondriacal concerns and the five factor model of personality. J Pers 2000 Aug;68(4):705-724 [FREE Full text] [doi: 10.1111/1467-6494.00113] [Medline: 10934687]

21. Green JS, Teachman BA. Predictive Validity of Explicit and Implicit Threat Overestimation in Contamination Fear. J Obsessive Compuls Relat Disord 2013 Jan 01;2(1):1-8 [FREE Full text] [doi: 10.1016/j.jocrd.2012.09.002] [Medline: $\underline{24073390]}$

22. Wang J, Li Y, Chen J, Liang W, Yang T, Lee Y, et al. Investigating the Relationships among Stressors, Stress Level, and Mental Symptoms for Infertile Patients: A Structural Equation Modeling Approach. PLoS One 2015 Oct 20;10(10):e0140581 [FREE Full text] [doi: 10.1371/journal.pone.0140581] [Medline: 26484531]

23. Maier SF. Exposure to the stressor environment prevents the temporal dissipation of behavioral depression/learned helplessness. Biol Psychiatry 2001 May 01;49(9):763-773 [FREE Full text] [doi: 10.1016/s0006-3223(00)01095-7] [Medline: 11331084]

24. Cacioppo J, Tassinary L, Berntson G. The Handbook of Psychophysiology, 3rd Edition. Cambridge, UK: Cambridge University Press; 2007.

25. Kiecolt-Glaser JK. Psychoneuroimmunology: Psychology's Gateway to the Biomedical Future. Perspect Psychol Sci 2009 Jul;4(4):367-369 [FREE Full text] [doi: 10.1111/j.1745-6924.2009.01139.x] [Medline: 19750133]

26. Romswinkel E, König HH, Hajek A. The role of optimism in the relationship between job stress and depressive symptoms. Longitudinal findings from the German Ageing Survey. J Affect Disord 2018 Dec 01;241:249-255 [FREE Full text] [doi: 10.1016/j.jad.2018.08.005] [Medline: $\underline{\text { 30138809] }}$

27. Broekhof R, Rius-Ottenheim N, Spinhoven P, van der Mast RC, Penninx BW, Zitman FG, et al. Long-lasting effects of affective disorders and childhood trauma on dispositional optimism. J Affect Disord 2015 Apr 01;175:351-358 [FREE Full text] [doi: 10.1016/j.jad.2015.01.022] [Medline: 25665495]

28. Scheve C, Salmela M. Collective Emotions. Oxford, UK: Oxford University Press; 2014.

29. Taylor S, Asmundson GJG. Treatment of Health Anxiety. In: The Wiley Handbook of Obsessive Compulsive Disorders, Volume II. Hoboken, NJ: Wiley; 2017:977-989.

30. Luo Y, Yao L, Zhou L, Yuan F, Zhong X. Factors influencing health behaviours during the coronavirus disease 2019 outbreak in China: an extended information-motivation-behaviour skills model. Public Health 2020 Aug;185:298-305 [FREE Full text] [doi: 10.1016/j.puhe.2020.06.057] [Medline: $\underline{32717671]}$

31. Ahmad M, Iram K, Jabeen G. Perception-based influence factors of intention to adopt COVID-19 epidemic prevention in China. Environ Res 2020 Jul 27;190:109995 [FREE Full text] [doi: 10.1016/j.envres.2020.109995] [Medline: 32739626]

32. Ariely D. Predictably Irrational: The Hidden Forces That Shape Our Decisions. New York, NY: Harper Collins; 2008.

33. Lee JD. An Epidemic of Rumors: How Stories Shape Our Perception of Disease. Logan, UT: Utah State University Press; 2014.

34. Zheng L, Miao M, Lim J, Li M, Nie S, Zhang X. Is Lockdown Bad for Social Anxiety in COVID-19 Regions?: A National Study in The SOR Perspective. Int J Environ Res Public Health 2020 Jun 24;17(12):4561 [FREE Full text] [doi: 10.3390/ijerph17124561] [Medline: 32599911]

35. Shultz J, Espinel Z, Flynn B, Hoffmann Y, Cohen R. DEEP PREP All-Hazards Disaster Behavioral Health Training. Coral Gables, FL: DEEP Center, University of Miami; 2008.

36. Dezecache G. Human collective reactions to threat. Wiley Interdiscip Rev Cogn Sci 2015 Feb 20;6(3):209-219 [FREE Full text] [doi: 10.1002/wcs.1344] [Medline: 26263225]

37. Ursano RJ, Norwood AE, Fullerton CS. Bioterrorism: Psychological and Public Health Interventions. Cambridge, UK: Cambridge University Press; Mar 17, 2005:595-596.

38. He F, Guan H, Kong Y, Cao R, Peng J. Some Individual Differences Influencing the Propensity to Happiness: Insights from Behavioral Economics. Soc Indic Res 2013 Dec 8;119(2):897-908 [FREE Full text] [doi: 10.1007/s11205-013-0519-0]

39. Wang X, Cai L, Qian J, Peng J. Social support moderates stress effects on depression. Int J Ment Health Syst 2014;8(1):41 [FREE Full text] [doi: 10.1186/1752-4458-8-41] [Medline: 25422673]

40. Maulik PK, Eaton WW, Bradshaw CP. The role of social network and support in mental health service use: findings from the Baltimore ECA study. Psychiatr Serv 2009 Sep;60(9):1222-1229 [FREE Full text] [doi: 10.1176/ps.2009.60.9.1222] [Medline: 19723737]

41. Dalton L, Rapa E, Stein A. Protecting the psychological health of children through effective communication about COVID-19. Lancet Child Adolesc Health 2020 May;4(5):346-347 [FREE Full text] [doi: 10.1016/s2352-4642(20)30097-3]

42. Yang Y, Li W, Zhang Q, Zhang L, Cheung T, Xiang Y. Mental health services for older adults in China during the COVID-19 outbreak. Lancet Psychiat 2020 Apr;7(4):e19 [FREE Full text] [doi: 10.1016/S2215-0366(20)30079-1] [Medline: 32085843]

43. Ahorsu DK, Lin C, Imani V, Saffari M, Griffiths MD, Pakpour AH. The Fear of COVID-19 Scale: Development and Initial Validation. Int J Ment Health Addiction 2020 Mar 27:6353-6359. [doi: 10.1007/s11469-020-00270-8] [Medline: 32226353]

44. Wang C, Pan R, Wan X, Tan Y, Xu L, Ho CS, et al. Immediate Psychological Responses and Associated Factors during the Initial Stage of the 2019 Coronavirus Disease (COVID-19) Epidemic among the General Population in China. Int J Environ Res Public Health 2020 Mar 06;17(5):1729 [FREE Full text] [doi: 10.3390/ijerph17051729] [Medline: 32155789]

45. Choi EPH, Hui BPH, Wan EYF. Depression and Anxiety in Hong Kong during COVID-19. Int J Environ Res Public Health 2020 May 25;17(10):3740 [FREE Full text] [doi: 10.3390/ijerph17103740] [Medline: $\underline{\text { 32466251] }}$ 
46. Gómez-Salgado J, Andrés-Villas M, Domínguez-Salas S, Díaz-Milanés D, Ruiz-Frutos C. Related Health Factors of Psychological Distress During the COVID-19 Pandemic in Spain. Int J Environ Res Public Health 2020 Jun 02;17(11):3947 [FREE Full text] [doi: 10.3390/ijerph17113947] [Medline: $\underline{\text { 32498401] }}$

47. Huang Y, Zhao N. Generalized anxiety disorder, depressive symptoms and sleep quality during COVID-19 outbreak in China: a web-based cross-sectional survey. Psychiatry Res 2020 Jun;288:112954 [FREE Full text] [doi: 10.1016/j.psychres.2020.112954] [Medline: 32325383]

48. Gao J, Zheng P, Jia Y, Chen H, Mao Y, Chen S, et al. Mental health problems and social media exposure during COVID-19 outbreak. PLoS One 2020;15(4):e0231924 [FREE Full text] [doi: 10.1371/journal.pone.0231924] [Medline: $\underline{32298385]}$

49. Yang X, Kovarik CL. A systematic review of mobile health interventions in China: Identifying gaps in care. J Telemed Telecare 2019 Jul 18:1357633X19856746. [doi: 10.1177/1357633X19856746] [Medline: 31319759]

50. Cai B, Xu Z. Investigation on reading behaviors of medical science articles in Wechat public platform. Article in Chinese. Journal of Public Health Management 2016 Jun:783-787.

51. Kroenke K, Spitzer RL. The PHQ-9: A New Depression Diagnostic and Severity Measure. Psychiatric Annals 2002 Sep 01;32(9):509-515. [doi: 10.3928/0048-5713-20020901-06]

52. Manea L, Gilbody S, McMillan D. A diagnostic meta-analysis of the Patient Health Questionnaire-9 (PHQ-9) algorithm scoring method as a screen for depression. Gen Hosp Psychiatry 2015;37(1):67-75 [FREE Full text] [doi: 10.1016/j.genhosppsych.2014.09.009] [Medline: 25439733]

53. Moriarty AS, Gilbody S, McMillan D, Manea L. Screening and case finding for major depressive disorder using the Patient Health Questionnaire (PHQ-9): a meta-analysis. Gen Hosp Psychiatry 2015;37(6):567-576 [FREE Full text] [doi: 10.1016/j.genhosppsych.2015.06.012] [Medline: 26195347]

54. Manea L, Gilbody S, McMillan D. Optimal cut-off score for diagnosing depression with the Patient Health Questionnaire (PHQ-9): a meta-analysis. CMAJ 2012 Feb 21;184(3):E191-E196 [FREE Full text] [doi: 10.1503/cmaj.110829] [Medline: 22184363]

55. Levis B, Benedetti A, Thombs BD, DEPRESsion Screening Data (DEPRESSD) Collaboration. Accuracy of Patient Health Questionnaire-9 (PHQ-9) for screening to detect major depression: individual participant data meta-analysis. BMJ 2019 Apr 09;365:11476 [FREE Full text] [doi: 10.1136/bmj.11476] [Medline: $\underline{\text { 30967483] }}$

56. Zhao D, Hu C, Chen J, Dong B, Ren Q, Yu D, et al. Risk factors of geriatric depression in rural China based on a generalized estimating equation. Int Psychogeriatr 2018 Oct;30(10):1489-1497 [FREE Full text] [doi: 10.1017/S1041610218000030] [Medline: 29380720]

57. Lu S, Reavley N, Zhou J, Su J, Pan X, Xiang Q, et al. Depression among the general adult population in Jiangsu Province of China: prevalence, associated factors and impacts. Soc Psychiatry Psychiatr Epidemiol 2018 Oct 30;53(10):1051-1061 [FREE Full text] [doi: 10.1007/s00127-018-1568-0] [Medline: $\underline{\text { 30062483] }}$

58. Ryder AG, Sun J, Zhu X, Yao S, Chentsova-Dutton YE. Depression in China: integrating developmental psychopathology and cultural-clinical psychology. J Clin Child Adolesc Psychol 2012;41(5):682-694 [FREE Full text] [doi: 10.1080/15374416.2012.710163] [Medline: 22900498]

59. Tao J, Gong F, Lu J, Liang L, Liao X. Meta-analysis on the prevalence of depressive and /or anxiety disorder in general hospitals in China. Article in Chinese. Sichuan Mental Health 2018;31:73-78. [doi: 10.11886/j.issn.1007-3256.2018.01.018]

60. Lee DTS, Sahota D, Leung TN, Yip ASK, Lee FFY, Chung TKH. Psychological responses of pregnant women to an infectious outbreak: a case-control study of the 2003 SARS outbreak in Hong Kong. J Psychosom Res 2006 Nov;61(5):707-713 [FREE Full text] [doi: 10.1016/j.jpsychores.2006.08.005] [Medline: 17084150]

61. Smith GD, Ng F, Ho Cheung Li W. COVID-19: Emerging compassion, courage and resilience in the face of misinformation and adversity. J Clin Nurs 2020 May;29(9-10):1425-1428 [FREE Full text] [doi: 10.1111/jocn.15231] [Medline: 32155302]

62. Zhang W, Wang K, Yin L, Zhao W, Xue Q, Peng M, et al. Mental Health and Psychosocial Problems of Medical Health Workers during the COVID-19 Epidemic in China. Psychother Psychosom 2020;89(4):242-250 [FREE Full text] [doi: 10.1159/000507639] [Medline: $\underline{32272480]}$

63. Chen Q, Liang M, Li Y, Guo J, Fei D, Wang L, et al. Mental health care for medical staff in China during the COVID-19 outbreak. Lancet Psychiat 2020 Apr;7(4):e15-e16 [FREE Full text] [doi: 10.1016/S2215-0366(20)30078-X] [Medline: $\underline{32085839]}$

64. Liu Y, Cao L, Li X, Jia Y, Xia H. Awareness of mental health problems in patients with coronavirus disease 19 (COVID-19): A lesson from an adult man attempting suicide. Asian J Psychiatr 2020 Jun;51:102106 [FREE Full text] [doi: 10.1016/j.ajp.2020.102106] [Medline: 32334411]

65. Anmella G, Arbelo N, Fico G, Murru A, Llach C, Madero S, et al. COVID-19 inpatients with psychiatric disorders: Real-world clinical recommendations from an expert team in consultation-liaison psychiatry. J Affect Disord 2020 Sep 01;274:1062-1067 [FREE Full text] [doi: 10.1016/j.jad.2020.05.149] [Medline: 32663933]

66. Yao H, Chen J, Xu Y. Patients with mental health disorders in the COVID-19 epidemic. Lancet Psychiat 2020 Apr;7(4):e21 [FREE Full text] [doi: 10.1016/S2215-0366(20)30090-0] [Medline: 32199510]

67. Schibalski JV, Müller M, Ajdacic-Gross V, Vetter S, Rodgers S, Oexle N, et al. Stigma-related stress, shame and avoidant coping reactions among members of the general population with elevated symptom levels. Compr Psychiatry 2017 Apr;74:224-230 [FREE Full text] [doi: 10.1016/j.comppsych.2017.02.001] [Medline: 28236772] 
68. Goulia P, Mantas C, Dimitroula D, Mantis D, Hyphantis T. General hospital staff worries, perceived sufficiency of information and associated psychological distress during the A/H1N1 influenza pandemic. BMC Infect Dis 2010 Nov 09;10:322 [FREE Full text] [doi: 10.1186/1471-2334-10-322] [Medline: 21062471]

69. Maguire PA, Reay RE, Looi JC. A sense of dread: affect and risk perception in people with schizophrenia during an influenza pandemic. Australas Psychiatry 2019 Oct;27(5):450-455 [FREE Full text] [doi: 10.1177/1039856219839467] [Medline: $\underline{\text { 30983379] }}$

70. Alkhamees AA, Alrashed SA, Alzunaydi AA, Almohimeed AS, Aljohani MS. The psychological impact of COVID-19 pandemic on the general population of Saudi Arabia. Compr Psychiatry 2020 Jul 12;102:152192 [FREE Full text] [doi: 10.1016/j.comppsych.2020.152192] [Medline: 32688022]

71. Wang D, Hu B, Hu C, Zhu F, Liu X, Zhang J, et al. Clinical Characteristics of 138 Hospitalized Patients With 2019 Novel Coronavirus-Infected Pneumonia in Wuhan, China. JAMA 2020 Feb 07;323(11):1061-1069 [FREE Full text] [doi: 10.1001/jama.2020.1585] [Medline: $\underline{32031570]}$

72. Zainal NH, Newman MG. Worry amplifies theory-of-mind reasoning for negatively valenced social stimuli in generalized anxiety disorder. J Affect Disord 2018 Feb;227:824-833 [FREE Full text] [doi: 10.1016/j.jad.2017.11.084] [Medline: 29254067]

73. Fanti KA, Hellfeldt K, Colins OF, Meehan A, Andershed A, Andershed H. Worried, sad, and breaking rules? Understanding the developmental interrelations among symptoms of anxiety, depression, and conduct problems during early childhood. J Crim Justice 2019 May;62:23-28 [FREE Full text] [doi: 10.1016/j.jcrimjus.2018.09.006]

74. Heinen I, Bullinger M, Kocalevent R. Perceived stress in first year medical students - associations with personal resources and emotional distress. BMC Med Educ 2017 Jan 06;17(1):4 [FREE Full text] [doi: 10.1186/s12909-016-0841-8] [Medline: 28056972]

75. Trindade IA, Mendes AL, Ferreira NB. The moderating effect of psychological flexibility on the link between learned helplessness and depression symptomatology: A preliminary study. J Contextual Behav Sci 2020 Jan;15:68-72 [ㅌREE Full text] [doi: 10.1016/j.jcbs.2019.12.001]

76. Leung GM, Lam T, Ho L, Ho S, Chan BHY, Wong IOL, et al. The impact of community psychological responses on outbreak control for severe acute respiratory syndrome in Hong Kong. J Epidemiol Community Health 2003 Nov;57(11):857-863 [FREE Full text] [doi: 10.1136/jech.57.11.857] [Medline: 14600110]

77. Ho RC, Zhang MW, Ho CS, Pan F, Lu Y, Sharma VK. Impact of 2013 south Asian haze crisis: study of physical and psychological symptoms and perceived dangerousness of pollution level. BMC Psychiatry 2014 Mar 19;14:81 [타EE Full text] [doi: 10.1186/1471-244X-14-81] [Medline: 24642046]

78. Li S, Wang Y, Xue J, Zhao N, Zhu T. The Impact of COVID-19 Epidemic Declaration on Psychological Consequences: A Study on Active Weibo Users. Int J Environ Res Public Health 2020 Mar 19;17(6):2032 [FREE Full text] [doi: 10.3390/ijerph17062032] [Medline: 32204411]

79. Roohafza HR, Afshar H, Keshteli AH, Mohammadi N, Feizi A, Taslimi M, et al. What's the role of perceived social support and coping styles in depression and anxiety? J Res Med Sci 2014 Oct;19(10):944-949 [FREE Full text] [Medline: 25538777]

80. Lei L, Huang X, Zhang S, Yang J, Yang L, Xu M. Comparison of Prevalence and Associated Factors of Anxiety and Depression Among People Affected by versus People Unaffected by Quarantine During the COVID-19 Epidemic in Southwestern China. Med Sci Monit 2020 Apr 26;26:e924609 [FREE Full text] [doi: 10.12659/MSM.924609] [Medline: $\underline{32335579]}$

\section{Abbreviations \\ HMR: hierarchical multiple regression \\ OR: odds ratio \\ PHQ-9: Patient Health Questionnaire-9}

Edited by G Eysenbach; submitted 06.07.20; peer-reviewed by EPH Choi; comments to author 17.07.20; revised version received
05.08.20; accepted 10.08.20; published 04.09.20
Please cite as:
Zhang W, Yang X, Zhao J, Yang F, Jia Y, Cui C, Yang X
Depression and Psychological-Behavioral Responses Among the General Public in China During the Early Stages of the COVID-19
Pandemic: Survey Study
J Med Internet Res $2020 ; 22(9): e 22227$
URL: $\underline{\text { https://www.jmir.org/2020/9/e22227 }}$
doi: $\underline{10.2196 / 22227}$
PMID: $\underline{32886066}$


(C) Weiyu Zhang, Xiaoting Yang, Jinfeng Zhao, Fengzhi Yang, Yajing Jia, Can Cui, Xiaoshi Yang. Originally published in the Journal of Medical Internet Research (http://www.jmir.org), 04.09.2020. This is an open-access article distributed under the terms of the Creative Commons Attribution License (https://creativecommons.org/licenses/by/4.0/), which permits unrestricted use, distribution, and reproduction in any medium, provided the original work, first published in the Journal of Medical Internet Research, is properly cited. The complete bibliographic information, a link to the original publication on http://www.jmir.org/, as well as this copyright and license information must be included. 